\title{
SYN-COLLISIONAL PERALUMINOUS MAGMATISM IN THE RIO DOCE REGION: MINERALOGY, GEOCHEMISTRY AND ISOTOPIC DATA OF THE NEOPROTEROZOIC URUCUM SUITE (EASTERN MINAS GERAIS STATE, BRAZIL)
}

\author{
HERMÍNIO ARIAS NALINI JR. ${ }^{1}$, ESSAID BILAL ${ }^{2}$ AND JOSÉ MARQUES CORREIA NEVES ${ }^{3}$
}

\begin{abstract}
The Urucum Suite granitoids (Rio Doce region, southeastern Brazil) contains four main facies: megafeldspar granites, deformed medium- to coarse-grained granites, tourmaline, and pegmatitic facies. They intrude both the staurolite-garnet-muscovite-biotite schist of the São Tomé Formation (Rio Doce Group) and the Galiléia metaluminous suite (596 \pm 4 Ma). Detailed structural studies suggest that the Urucum Suite emplaced during an important dextral strike-slip movement ( $D_{1}$ phase) of the Brasiliano orogeny (650-450Ma). Modal and chemical mineralogical variations suggest an evolution from the megafeldspar facies to the pegmatitic facies. Whole-rock geochemistry indicates the peraluminous character of the Urucum Suite granitoids, the evolution from the megafeldspar facies granites to pegmatitic facies granites and suggests the syn-collisional character of this suite. U-Pb zircon (582 $\pm 2 \mathrm{Ma})$ and monazite (576-573 $\pm 4 \mathrm{Ma})$ data indicate that the Urucum Suite emplaced during the Brasiliano orogeny. The peraluminous nature of the Suite and isotopic-rich character in the $\mathrm{Rb}-\mathrm{Sr}\left({ }^{87} \mathrm{Sr} /{ }^{86} \mathrm{Sr}=0.7114\right.$ to 0.7165$)$ and $\mathrm{Sm}-\mathrm{Nd}\left(\mathrm{eNd}_{\mathrm{T}}=-7.4\right.$ and -8.2$)$ systems indicate that it formed by partial melting of older intermediate to felsic crustal sources. Based on early Proterozoic model-ages $(2.3$ to $1.8 \mathrm{Ga}$ ) and on $2.0 \mathrm{Ga} \mathrm{U}-\mathrm{Pb}$ inherited signature, granitoids of the Suite are probably derived from a rocks with a long crustal residence (Transamazonian basement), without extensive mantle contribution.
\end{abstract}

Keywords: granitoids, peraluminous, geochemistry, isotopic data, Neoproterozoic

\section{INTRODUCTION}

Peraluminous granitoid suites form small but genetically important components of granitic intrusions in most orogenic belts. Models for the origin of peraluminous granitoids emphasize the importance of the composition of the source rock and partial melting (Chappell and White 1974, 1977, 1992), and crystal fractionation as the main controls of the chemical variation in these suites (Bateman and Chappell 1979), and mixing of granitic melts derived from metasedimentary rocks and more mafic materials (Gray 1984). Peraluminous leucogranites are of great interest as they may help us understand the syn-collisional magmatism and the tectonic evolution of the continental crust during tectono-thermal events.

The Galiléia-Conselheiro Pena region (Rio Doce region, eastern of the Minas Gerais State, Brazil) is an excellent area to study the constraints of leucogranite emplacement, petrogenesis and the relation between leucogranites and complex rare-element pegmatites. The aims of this paper are 1) to characterize the mineralogy, geochemistry and some crystallization conditions of the leucogranites of the Neoproterozoic Urucum Suite; 2) to constrain the timing (U-Pb geochronological data) and source rocks ( $\mathrm{Rb}-\mathrm{Sr}$ and $\mathrm{Sm}-\mathrm{Nd}$ isotopic geochemical data) of the syn-collisional magmatism associated with the Brasiliano orogeny (650-450 Ma) in the Rio Doce region.

GEOLOGICAL SETTINGS The Rio Doce region is located within the northern Mantiqueira structural province (Almeida et al. 1981), east of the São Francisco cratonic block (Almeida 1977), southeastern Brazil (Fig. 1). The northern Mantiqueira province is interpreted as been connected to the West-African Congo fold belt (Porada 1989) before the South Atlantic rifting (Early Cretaceous). It comprises the Araçuaí (Almeida and Hasui 1984) and the Atlantic or Coastal (Leonardos and Fyfe 1974, Mascarenhas 1979) belts with poorly defined limits.

The first geological works in the Rio Doce region aimed to recognize different lithological units and identify rare elements and gem-bearing pegmatites (Barbosa et al. 1964, Fanton et al. 1978, Moura et al. 1978, Silva et al. 1987).

The Galiléia-Conselheiro Pena region consists of an Archean to Early Proterozoic amphibolite- to granulite-facies gneiss (Pocrane complex), supracrustal rocks represented by garnet-staurolitemuscovite-biotite schists (São Tomé Formation of the Rio Doce Group) and sericite quartzites (Crenaque Group) considered of Neoproterozoic age, and by two granitoid suites (Galiléia and Urucum suites) and intrusions of rare-element pegmatites associated with the Brasiliano orogeny (650-450 Ma). The Galiléia metaluminous suite (594 $\pm 6 \mathrm{Ma}$, Nalini Jr. 1997) is characterized by an expressive polydiapiric batholith. The suite consists of granodiorite, with subordinate tonalite and granite. The Galiléia Suite has been associated with the syn- to late-collisional phase of the Rio Doce Orogeny (Campos Neto and Figueiredo 1995) and, recently, with the pre-collisional magmatism of the Brasiliano orogeny (Nalini Jr. 1997). The Urucum Suite consists of different facies of two mica leucogranites that intruded the Galiléia Suite and the Rio Doce Group metasediments.

Cunningham et al. (1996) proposed for the region located between Galiléia and Conceição de Tronqueiras towns (about $80 \mathrm{~km}$ toward the west) a structural style represented by west-trending (shallow eastdipping gneissic foliation) overthrust of rigid basement blocks over metasedimentary sequences.

Detailed structural studies in the Galiléia-Conselheiro Pena region (Nalini Jr. 1997) point to two deformation phases and a medium grade metamorphism as the main effects of the Brasiliano orogeny. $\mathrm{D}_{1}$ is the main deformational phase and is characterized by a N-NW highangle foliation and by oblique to horizontal mineral stretching lineation. Such set of structures is related to an important dextral strike-slip movement. D is also responsible for the ascension and emplacement of the Galiléia metaluminous and the Urucum peraluminous suites. The second phase $\left(D_{2}\right)$ involves a crenulation cleavage, boudinage and normal faults related to a late extensional phase. Both phases fit in a regional transpressional regime (Nalini Jr. 1997).

PETROGRAPHY AND MINERALOGY Circular and elliptical (NW-SE) plutons of the Urucum Suite (Fig. 1) intrude both the metasediments of the São Tomé Formation and the Galiléia metaluminous suite. Four granitoid facies with distinct lithological features were determined in the field: a feldspar megacryst $(5$ to $10 \mathrm{~cm})$ facies (megafeldspar facies), a highly deformed medium- to coarsegrained facies, a tourmaline facies, and a highly fractionated pegmatitic facies (associated with gem-bearing rare-element pegmatites). Detailed petrographic analysis and geochemical evidence confirm these initial distinctions. The strike slip deformation and the syn-kinematic character of these granitoids are indicated by the parallel solid-state and magmatic flow foliation oriented according to the foliation of the São Tomé schist. The intrusive contacts are often marked by decimetric to metric granitic veins. Xenoliths of the São Tomé schist are common, mainly near the contacts.

Rocks of the Urucum Suite are composed by plagioclase ( $\left.\mathrm{An}_{2}\right)$, potassic feldspar $\left(\mathrm{Or}_{97-91}\right)$, biotite, muscovite, garnet, tourmałline, monazite, zircon and apatite.

Biotite contents decrease from the megafeldspar facies to the pegmatitic facies. The proportion of biotite controls the $\mathrm{MgO}$ content of the rock. Biotite $m g(=\mathrm{MgO} /(\mathrm{FeO}+\mathrm{MgO}))$ lies between 40 (megafeldspar facies) and 27 (tourmaline and pegmatitic facies) and $\mathrm{Al}_{2} \mathrm{O}_{3}$ between 18 and $20 \%$. It plots in the peraluminous aluminopotassic field of the Nachit's et al. (1988) diagram (Fig. 2A). This composition is comparable to that of biotite of the Guéret type granites in the French Central Massif (Chevremont et al. 1988).

Muscovite is present in all facies. It is slightly iron-rich $(0.53<\mathrm{FeO}$ $<2.48 \%$ ) and magnesian $(0.34<\mathrm{MgO}<1.19 \%)$. The $m g$ (71 to 34) and $\mathrm{TiO}(1.89 \%$ to $0.09 \%)$ contents decrease from the megafeldspar facies to the pegmatitic facies. Muscovite Ti contents are related to the crystallization temperature (Guidotti et al. 1977), as its crystallization

1 - Departamento de Geologia, Escola de Minas, Universidade Federal de Ouro Preto, Campus Morro do Cruzeiro, Ouro Preto, MG, 35400-000, Brazil, e-mail: nalini @degeo.ufop.br

2 - Ecole de Mines de Saint Etienne, Saint Etienne, 158, cours Fauriel, 42023, France

3 - Instituto de Geociências, Universidade Federal de Minas Gerais, Av. Antônio Carlos, 6627, 31270-901, Belo Horizonte, MG, Brazil. 


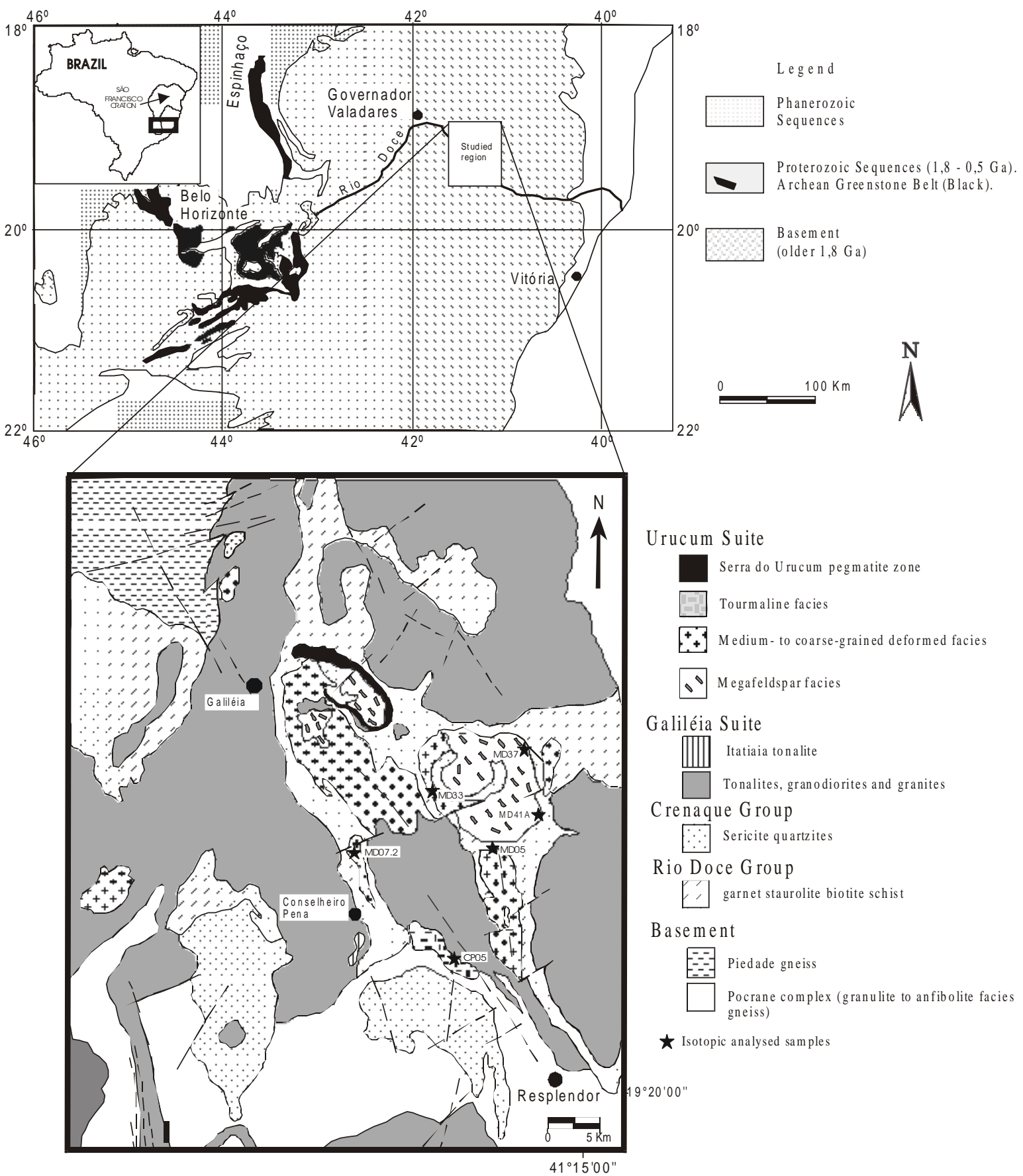

Figure 1 - Geological map of the studied region at the southeastern Brazil (modify from Barbosa et al. 1964). Archean to Early Proterozoic basement: Piedade gneiss and Pocrane complex; Late Proterozoic supracrustals sequences: schists of the São Tomé Formation (Rio Doce group) and sericite quartzites of the Crenaque group; Galiléia Suite: tonalite, granodiorite and granite; Urucum Suite: megafeldspar granite, medium-to coarse-grained deformed granites, tourmaline granite and Serra do Urucum pegmatite zone.

temperature decreases from the megafeldspar to the pegmatitic facies. Urucum muscovite composition (Fig. 2B) is similar to the primary muscovite composition (Miller et al. 1981) and comparable to the St. Julien leucogranite muscovite of the Millevaches Massif in France (Monier et al. 1984).

The Urucum Suite garnet (Fig. 2C) is almandine-spessartite (up to $35 \%$ of spessartite). The evolved facies (tourmaline and pegmatitic facies) contain more garnet than the other facies. The late crystallization of garnet results from the increase of the $\mathrm{Mn} /(\mathrm{Mn}+\mathrm{Fe})$ ratio during the evolution of the Urucum Suite granitoids (Miller and Stoddard 1980). The importance of the role played by $\mathrm{MnO}$ in the genesis of granite garnets has been underlined by Green's (1977) applied studies. Manganese increases the field of garnet stability allowing its crystallization under very low pressures. According to Green, garnets with $20-25 \%$ of spessartite (thus comparable to garnet of the Urucum Suite) can crystallize in granitic liquids under pressures of $3 \mathrm{kbar}$ or less $(<12 \mathrm{~km})$.
Tourmaline is Fe-rich (schörl-dravite). Its evolution is given by the increase of $\mathrm{MnO} \quad(0.03<\mathrm{MnO}<0.47) \quad$ (Fig. 2D) and $\mathrm{FeO}$ $(5.88<\mathrm{FeO}<6.96 \%)$ and by decrease of $m g(50$ to 16$)$ and $\mathrm{TiO}_{2}(0.79 \%$ to $0.53 \%$ ) contents in the tourmalines of the tourmaline-facies granite to the most evolved pegmatitic-facies granite. It is often zoned (with a blue Fe-rich core and a green $\mathrm{Mg}$-rich border).

Modal proportions of monazite decrease from the megafeldspar and deformed medium- to coarse-grained facies to the tourmaline-facies granites. Monazite is absent in granitic pegmatoids and in complex pegmatites. It occurs in small oval inclusions in biotite and locally in muscovite suggesting the early character in this suite. The evolution of monazite composition is marked by increase of the light rare earth elements ( $\mathrm{La}$ and $\mathrm{Ce}$ ) and decrease of the Th, $\mathrm{U}, \mathrm{Y}, \mathrm{Si}$ and $\mathrm{Ca}$ from the megafeldspar to the medium- to coarse-grained facies.

The Urucum Suite zircon is represented by Pupin's (1976) L and S morphological types. The most prominent characteristic of these zircons is the pronounced development of prismatic faces (110). Some 
zircon crystals show a G1-type inherited core with a L- or S-type overgrowth. These types are characterized by low crystallization temperatures $\left(700^{\circ} \mathrm{C}\right.$ to $\left.600^{\circ} \mathrm{C}\right)$ under crustal physical-chemical conditions (Pupin 1976). $\mathrm{HfO}_{2}$ contents of zircon vary between 1.04 and $3.95 \%$, compatible with crustal anatectic granites. The $\mathrm{Zr} / \mathrm{Hf}$ ratio varies between 53.11 and 27.8 . The highest ratio often represents inherited zircon cores identified in morphological studies.

Apatite is a fluor-apatite $(2.77<\mathrm{F}<3.78 \%)$ and occurs as small acicular crystals, locally as inclusions in biotite, muscovite and feldspar.

\section{GEOCHEMISTRY}

The Urucum Suite granitoids are peraluminous (Fig. 3A). The aluminum saturation index ASI $=$ mol $\mathrm{Al}_{2} \mathrm{O}_{3} /\left(\mathrm{CaO}+\mathrm{Na}_{2} \mathrm{O}+\mathrm{K}_{2} \mathrm{O}\right)$ ranges from 0.98 to 1.38 with an average of 1.13. The $\mathrm{K}_{2} \mathrm{O}+\mathrm{Na}_{2} \mathrm{O}^{2}$ (6.8 to 9.2\%) and $\mathrm{Al}_{2} \mathrm{O}_{3}$ (13.5 to $\left.15.09 \%\right)$ contents increase from the megafeldspar facies to the pegmatitic facies These rocks are relatively richer in $\mathrm{Na}_{2} \mathrm{O}$ (up to $4.4 \%$ ) than Chappell and White's (1974) S-type granites, but $\mathrm{Na}_{2} \mathrm{O}$ contents are comparable to those of the Himalayan Manaslu leucogranites (Vidal et al. 1982 , 1984). The peraluminous character of the Urucum Suite is indicated by the presence of muscovite, garnet, tourmaline, and by the permanent presence of normative corindon (up to $4.7 \%$ ).

The evolution of the Urucum Suite is marked by FMMT $\left(\mathrm{Fe}_{2} \mathrm{O}_{3}{ }^{\mathrm{T}}+\mathrm{MgO}+\mathrm{MnO}+\mathrm{TiO}_{2}\right)$ decrease accompanied by $\mathrm{SiO}_{2}$ increase during differentiation ( $\mathrm{Fig}$. 3B). This behavior results from the fractionation of biotite and tourmaline. The $\mathrm{MgO} / \mathrm{TiO}$, ratio ranges between 2.14 and 5.33, increasing in the pegmatitic facies granitoids (average $=5.17$ ). The $\mathrm{MnO} /\left(\mathrm{MnO}+\mathrm{Fe}_{2} \mathrm{O}_{3}{ }^{\mathrm{T}}\right.$ ) ratio increases from the megafeldspar facies to the pegmatitic facies resulting in a more important crystallization of almandine-spessartite in the most evolved facies (tourmaline and pegmatitic facies). $\mathrm{Rb}$ contents range between 262 to $121 \mathrm{ppm}$ and $\mathrm{Ba}$ contents between 464 to $63 \mathrm{ppm}$. The compatible behavior of the transition elements $(\mathrm{Co}, \mathrm{V}, \mathrm{Zn}$ and $\mathrm{Ga})$ is controlled by biotite fractionation, whereas $\mathrm{Zr}$ (143 to $26 \mathrm{ppm}$ ), Hf, Th
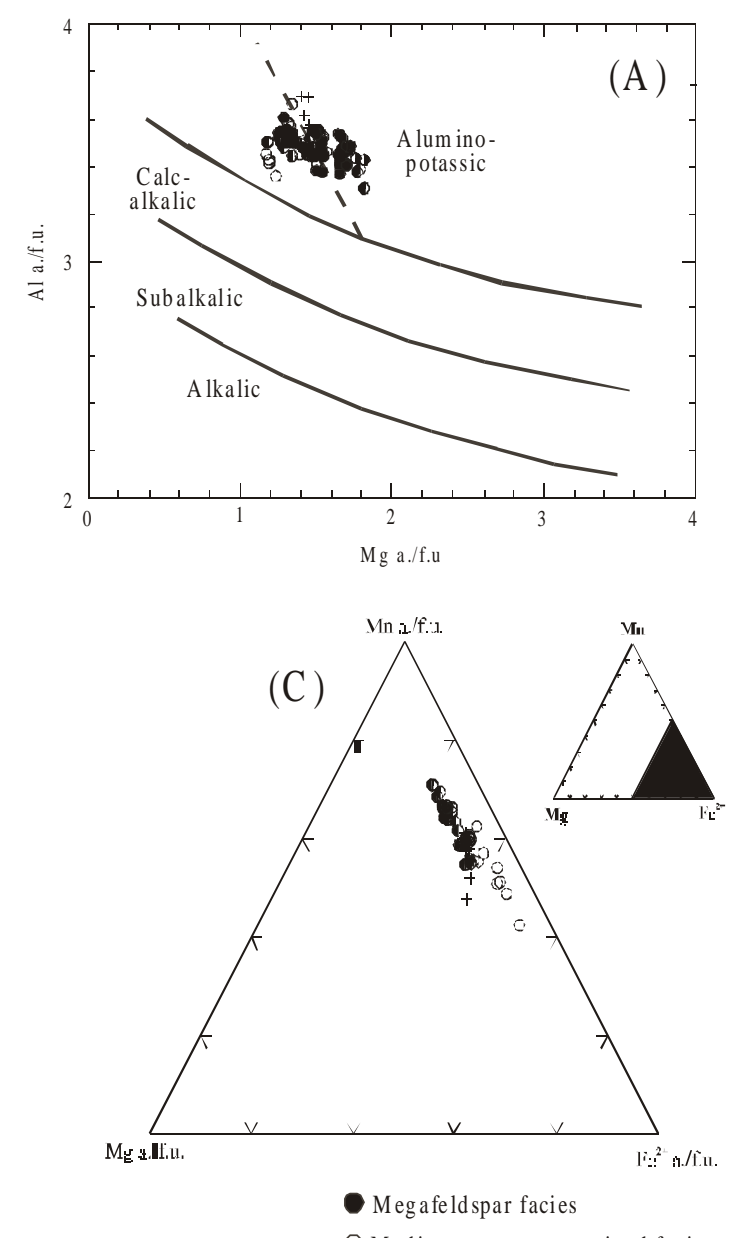

Medium - to coarse-grained facies and REE (113 to $17 \mathrm{ppm}$ ) have a compatible behavior controlled by the early fractionation of zircon and monazite (Figs. 3C and 3D). The REE spectra reflect the compatible behavior of the REE, which is characterized by $(\mathrm{La} / \mathrm{Yb})_{N}$ ranging from 31.6 (megafeldspar and deformed medium- to coarse-grained facies) to 2.8 (pegmatitic facies), and presence of important negative Eu anomalies. The Th/ $\mathrm{U}$ ratio $(0.30$ to 4.33) is controlled by monazite extraction. $\mathrm{P}, \mathrm{Be}, \mathrm{Cs}, \mathrm{Li}, \mathrm{Ta}$ and $\mathrm{B}$ show incompatible evolution resulting in a fertile residual liquid responsible for the crystallization of complex gem-bearing rareelement pegmatites. The Urucum Suite granitoids plot in the syncollisional field in tectonic diagrams (Figs. 3E and 3F).

\section{CONDITIONS OF CRYSTALLIZATION OF THE URUCUM}

\section{SUITE MAGMAS From the application of the zircon saturation} (Watson and Harrison 1984), monazite light rare earth element content (Montel 1993) and biotite-muscovite (Monier and Robert 1986) geothermometers, it is reasonable to consider that the crystallization temperature of megafeldspar- and medium- to coarse- grained facies granitoids ranges between $750-700^{\circ} \mathrm{C}$. Crystallization of such facies was followed by the crystallization of the tourmaline facies around $700-650^{\circ} \mathrm{C}$ and of the pegmatitic facies around $650-600^{\circ} \mathrm{C}$.

Crystallization of muscovite suggests a lower pressure limit for the crystallization of the Urucum Suite granitoids at $3.75 \mathrm{~Kb}$ (Kerrick 1972). The water contents in excess of 8-9 wt.\% and pressure in excess of about $4 \mathrm{~Kb}$ are necessary for the primary crystallization of muscovite from a granitoid melt (Burnham 1967).

The presence of Mn-rich garnet in the Urucum Suite is compatible with pressures of about $4 \mathrm{kbar}$ (depth of $12 \mathrm{~km}$ ). Garnets (20-25\% of spessartine) can be crystallized in equilibrium with a relatively lowpressure granitic melt, sometimes lower than 3 kbar (Green 1977).

ISOTOPIC RESULTS Four fractions of zircons of the deformed medium- to coarse-grained facies have been analyzed using the U-Pb isotopic method. Analytical results of three fractions (1 to 3; Table 1)
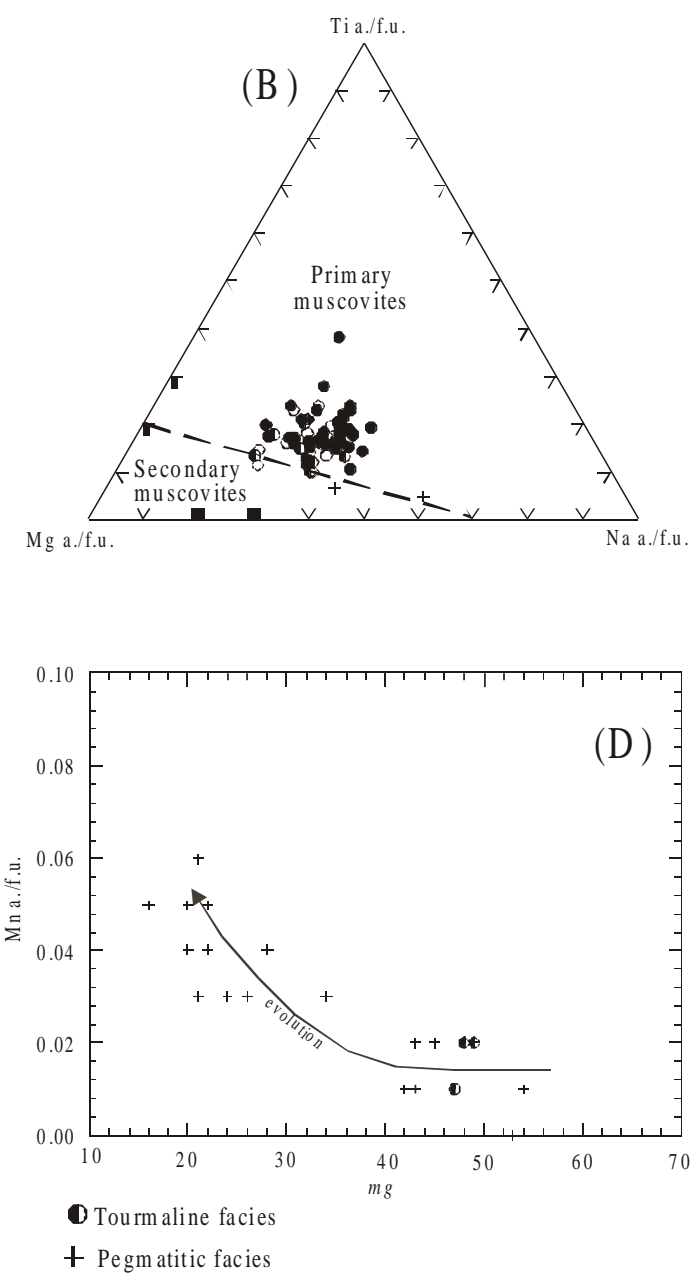

Figure 2 - (A) Classification Mg versus Al diagram for Urucum Suite biotite (Nachit et al. 1985); (B) Urucum Suite muscovite plotted in Na-Mg-Ti diagram (Miller et al.1981); (C) Almandine-spessartite composition of Urucum Suite garnets in Fe ${ }^{2+}-M g-M n$ diagram; (D) Evolution of Urucum Suite tourmaline in mg $(\mathrm{Mg} /(\mathrm{Mg}+\mathrm{Fe}))$ versus $\mathrm{Mn}$ diagram. a./f.u. = atoms/formula unit 
yield an U-Pb age of $582 \pm 2 \mathrm{Ma}$ (Fig. 4A). The fourth fraction (4) is very discordant and seems to indicate the presence of an isotopic inherited memory with an age about $2.2 \mathrm{Ga}$. In complement, two fractions indicate an age of $576 \pm 4 \mathrm{Ma}$ (Fig. 4A). This age is slightly younger than the one obtained from the zircon fractions, but it plots within the analytical error interval.

The four zircon fractions analyzed ( 7 to 10; Table 1) for the megafeldspar facies yield a lower intercept age of $570 \mathrm{Ma}$ and an upper intercept age of $2.2 \pm 0.3 \mathrm{Ga}$ (Fig. 4B). The last age is in accordance with fraction 4 from the medium- to coarse-grained facies, and confirms the presence of inherited zircon cores reported in the zircon morphological study (Nalini et al. 1997). Three monazite fractions analyzed (11 to 13; Table 1) for the megafeldspar facies indicate a crystallization age of $573 \pm 4 \mathrm{Ma}$ (Fig. 4B) that is comparable to the one obtained from the medium- to coarse-grained facies monazites (576 $\pm 4 \mathrm{Ma})$.

Initial ${ }^{87} \mathrm{Sr} /{ }^{86} \mathrm{Sr}$ isotopic ratio (Table 2) for Urucum Suite granitoids varies between 0.7114 to 0.7165 . The ratio increases according to the evolved character of the rocks, from the megafeldspar to the pegmatitic

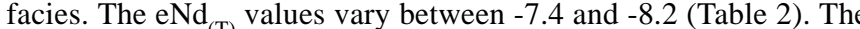
most negative value is observed in the tourmaline facies $(\mathrm{CP} 05 ; \varepsilon \mathrm{Nd}$
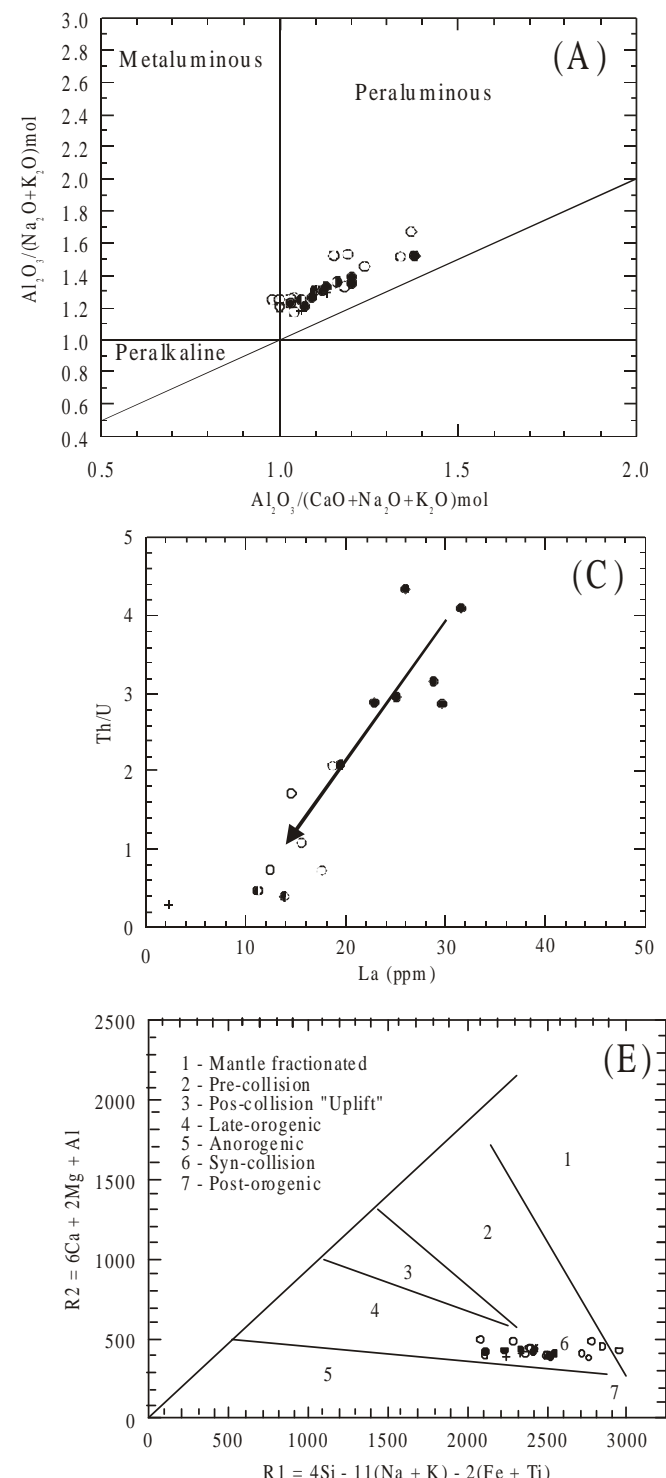

Megafeldspar facies

Medium- to coarse-grained facie monazite fractions (5 and 6; Table 1) have been analyzed. These

$=-8.2)$ and in one of the medium- to coarse-grained facies samples (MD33; eNd = -8.1). The pegmatitic facies shows an eNd value (-7.4) close to the others analyzed samples, which suggests a genetic link between the different facies of the Urucum Suite. $\mathrm{T}_{\mathrm{DM}}$ model ages obtained for two samples of the megafeldspar facies are about $1.8 \mathrm{Ga}$ (Table 2). Other facies yield older model ages (2.3 to $2.1 \mathrm{Ga}$ ). Such ages are in accordance with the presence of an isotopic-inherited memory in zircons of the megafeldspar $(2.0 \pm 0.3 \mathrm{Ga})$ and medium- to coarse-grained $(2.0 \mathrm{Ga})$ facies.

In summary, the U-Pb data show that the emplacement of the Urucum Suite occurred during the Neoproterozoic (Brasiliano orogeny) and the $\mathrm{Rb}-\mathrm{Sr}$ and $\mathrm{Sm}-\mathrm{Nd}$ isotopic results point to a strong crustal affinity for the Urucum Suite, whose origin is probably from reworking of an older Early Proterozoic (2.3 to $1.8 \mathrm{Ga} \mathrm{T}_{\mathrm{DM}}$ ages) basement.

CONCLUSION Urucum Suite leucogranite intrusions occurred by the end of the Brasiliano orogeny (582 $\pm 2 \mathrm{Ma}, \mathrm{U}-\mathrm{Pb}$ in zircon). These granitoids comprise four main facies: megafeldspar granites, deformed medium- to coarse-grained granites, tourmaline and pegmatitic facies. Modal mineralogical variations and chemical composition of biotite, muscovite, monazite, garnet and tourmaline suggest an evolution from the megafeldspar facies to the pegmatitic facies.
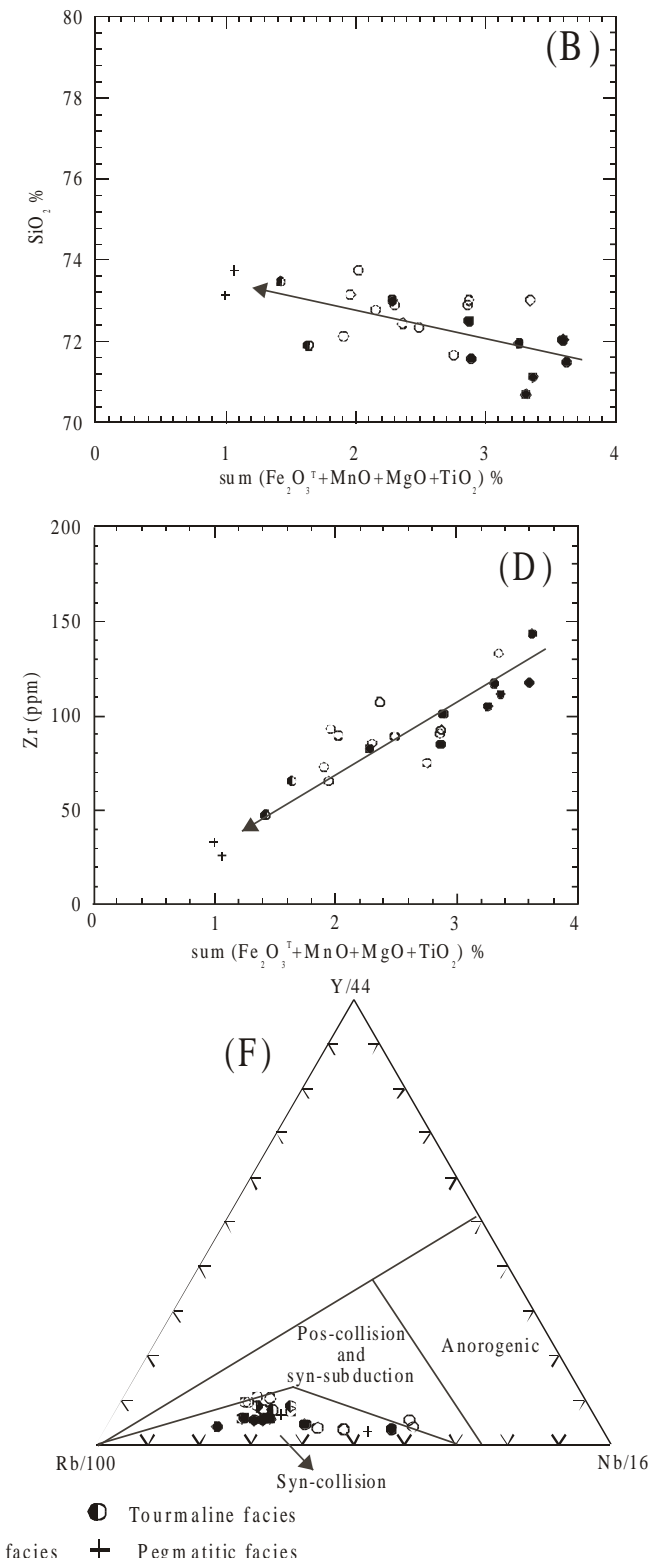

Figure 3- Whole rock geochemical diagrams of the Urucum Suite. (A) A/NK versus A/CNK diagram (Maniar \& Piccoli 1989); (B) $\left(\mathrm{Fe}_{2} \mathrm{O}_{3}{ }^{\mathrm{T}}+\mathrm{MnO}+\mathrm{MgO}+\mathrm{TiO}_{2}\right)$ versus $\mathrm{SiO}_{2}$ diagram. The arrow indicates the evolution trend of the suite rocks; $(\mathrm{C})$ and $(\mathrm{D}) \mathrm{La}$ versus $\mathrm{Th} / \mathrm{U}$ and $\left(\mathrm{Fe}_{2} \mathrm{O}_{3}{ }^{\mathrm{T}}+\mathrm{MnO}+\mathrm{MgO}+\mathrm{TiO} \mathrm{O}_{2}\right)$ versus $\mathrm{Zr}$ diagrams showing the monazite and zircon fractionation respectively; $(E) R 1$ versus $R 2$ diagram (La Roche et al. 1980) with the tectonic domains of Batchelor \& Bowden (1985); (F) Nb/16 - Rb/100 - Y/44 tectonic diagram proposed by Thièblemont \& Cabanis (1990). 
Structural studies (Nalini 1997) suggest the syn-kinematically emplacement of the Urucum collisional suite within a water-rich environment (primary muscovite). The emplacement is favored by magma canalization within a N to NW-trending, dextral strike-slip shear zone related to the end of the Brasiliano orogeny. Temperature and pressure estimations for the Urucum Suite crystallization occurred at $750-600^{\circ} \mathrm{C}$ and $4 \mathrm{kbar}$ (depth of $12 \mathrm{~km}$ ), respectively.

Chemical compositions indicate the peraluminous character of the Urucum Suite granitoids. The suite evolves from the megafeldspar facies granites to pegmatitic facies granites. Whole-rock chemical evolution is in accordance with the mineral-chemical evolution. The compatible behavior of certain elements ( $\mathrm{Fe}, \mathrm{Mg}, \mathrm{REE}, \mathrm{Zr}$, etc) clearly shows the role played by fractional crystallization of biotite, monazite and zircon in the evolution of these granitoids. However, other elements such as $\mathrm{Mn}, \mathrm{P}, \mathrm{Ta}, \mathrm{Li}$ and $\mathrm{B}$ show an incompatible behavior that is responsible for the fertile residual granitic melt from which the rare-element pegmatites originated. Geochemical signatures suggest the syn-collisional character of this suite.

The peraluminous composition and the enriched character of the isotopic $\mathrm{Rb}-\mathrm{Sr}\left({ }^{87} \mathrm{Sr} /{ }^{86} \mathrm{Sr}=0.7114\right.$ to 0.7165$)$ and $\mathrm{Sm}-\mathrm{Nd}\left(\mathrm{eNd}{ }_{(\mathrm{T})}=\right.$ 7.4 and -8.2) data indicate that the Urucum Suite rocks are formed by partial melting of older intermediate to felsic crustal sources (lowercrustal metasediments and/or metaigneous basement rocks). Based on early Proterozoic model ages (2.3 to $1.8 \mathrm{Ga}$ ) and on $2.0 \mathrm{Ga} \mathrm{U}-\mathrm{Pb}$ inherited isotopic memory, the leucogranites are probably derived from a crust with a long crustal residence time (Paleoproterozoic). Isotopic results agree with regional studies (Cordani et al. 1988, Ebert et al. 1996) that suggest an origin for the Brasiliano granitoids by reworking of the older Transamazonian basement $(2.2-1.8 \mathrm{Ga})$, without extensive mantle-derived contribution.

$\mathrm{U}-\mathrm{Pb}$ ages for the Urucum Suite are comparable to those of the peraluminous Rio Turvo massif ( $579 \pm 2 \mathrm{Ma}$, Valladares 1996), located in Rio de Janeiro State, south of the studied region. These granitoids appear to be relatively older $(\sim 10-20 \mathrm{Ma})$ than the collisional granitoids in Espírito Santo State, as proposed by Figueiredo and Campos Neto (1993) and Campos Neto and Figueiredo (1995). On other hand, these ages plot in the 600-570 Ma range as proposed by Machado (1997) for the collisional-phase magmatism in Rio de Janeiro State. Finally, considering the analytical errors, it seems that the collisional phase-magmatism associated with the Brasiliano orogeny in the Rio Doce region must be constrained between 585 and $570 \mathrm{Ma}$. The Urucum peraluminous magmatism postdates the pre-collisional calcalkaline magmatism of the Galiléia Suite in the Rio Doce region (596 \pm 4 Ma, Nalini 1997).

Acknowledgments Financial support for this research has been provided by CNPq, Capes/Cofecub, Fapemig and Fapesp. Logistic and laboratorial support by Ecole des Mines de Saint Etienne (Saint Etienne - France), Degeo/Universidade Federal de Ouro Preto (Brazil) and Université Blaise Pascal (Clermont Ferrand - France). To J.L. Paquette and Christian Pin for the isotopic analyses. To two anonymous referees of RBG for the critical analysis of the manuscript.

Table 1 - U-Pb analytical results of the Urucum suite; individual analyses were performed on the least magnetic $\left(3^{\circ}\right.$ forward and side tilt at $2.2 A$ using a Frantz magnetic barrier separator), euhedral and crack-and inclusion-free grains. The isotopic ratios are corrected for mass discrimination (0.1 $\pm 0.015 \%$ per uma for $\mathrm{Pb}$ and $\mathrm{U}$ ), isotopic tracer contribution and analytical blank: 5-10 pg for Pb and $1 \mathrm{pg}$ for U. Initial common Pb is determined using the Stacey and Kramers (1975) two-steps model. The errors on the isotopic ratios are given at the 2 s level. Abbreviations: $\mathrm{Zr} .=$ zircons; Mz.= monazites; na. $=$ unabraded; ab.= airabraded; in. = colourless; ja. $=$ yellow. Number in brackets is the number of grains in fraction.

\begin{tabular}{|c|c|c|c|c|c|c|c|c|c|c|c|}
\hline $\begin{array}{l}\text { Fraction } \\
(\mu \mathrm{m})\end{array}$ & $\begin{array}{l}\text { Poids } \\
(\mathrm{mg})\end{array}$ & $\begin{array}{c}\mathrm{U} \\
(\mathrm{ppm}) \\
\text { conce }\end{array}$ & $\begin{array}{l}\text { Pb rad } \\
(\mathrm{ppm}) \\
\text { ntrations }\end{array}$ & $\frac{{ }^{206} \mathrm{~Pb}}{{ }^{204} \mathrm{~Pb}}$ & $\begin{array}{l}\frac{{ }^{208} \mathrm{~Pb}}{{ }^{206} \mathrm{~Pb}} \\
\text { atomic ratio }\end{array}$ & $\frac{{ }^{206} \mathrm{~Pb}}{{ }^{238} \mathrm{U}}$ & $\frac{{ }^{207} \mathrm{~Pb}}{{ }^{235} \mathrm{U}}$ & $\frac{{ }^{207} \mathrm{~Pb}}{{ }^{206} \mathrm{~Pb}}$ & $\frac{{ }^{206} \mathrm{~Pb}}{{ }^{238} \mathrm{U}}$ & $\begin{array}{l}\frac{{ }^{207} \mathrm{~Pb}}{{ }^{235} \mathrm{U}} \\
\text { apparent }\end{array}$ & $\begin{array}{l}\frac{{ }^{207} \mathrm{~Pb}}{{ }^{206} \mathrm{~Pb}} \\
(M a)\end{array}$ \\
\hline \multicolumn{12}{|c|}{ Medium- to coarse-grained facies (sample MD07.2) } \\
\hline $1: \mathrm{Zr}>100 \mathrm{ab} .[9]$ & 0.056 & 159 & 16.3 & 1692 & 0.1843 & 0.09436 & 0.7728 & 0.05940 & 581 & 581 & 582 \\
\hline $2: \mathrm{Zr}>100 \mathrm{ab} .[10]$ & 0.076 & 151 & 14.3 & 4599 & 0.1005 & 0.09416 & 0.7714 & 0.05942 & 580 & 581 & 582 \\
\hline $3: \mathrm{Zr}>100 \mathrm{ab} .[9]$ & 0.074 & 157 & 14.9 & 4261 & 0.1104 & 0.09394 & 0.7695 & 0.04941 & 579 & 579 & 582 \\
\hline $4: \mathrm{Zr}>100 \mathrm{ab} .[12]$ & 0.096 & 287 & 51.8 & 19199 & 0.0996 & 0.1733 & 2.602 & 0.1089 & 1030 & 1301 & 1781 \\
\hline $5:$ Mz na. & 0.082 & 1188 & 1157 & 246 & 10.005 & 0.09436 & 0.7655 & 0.05926 & 577 & 577 & 577 \\
\hline $6:$ Mz na. & 0.111 & 1081 & 1122 & 322 & 11.007 & 0.09342 & 0.7632 & 0.05925 & 576 & 576 & 576 \\
\hline \multicolumn{12}{|c|}{$\underline{\text { Megafeldspar facies (sample MD41) }}$} \\
\hline $7: \mathrm{Zr}<75$ ab.in. [29] & 0.030 & 551 & 80.1 & 764 & 0.1672 & 0.1295 & 1.616 & 0.09051 & 785 & 976 & 1436 \\
\hline $8: \mathrm{Zr}<75$ ab.in. [22] & 0.029 & 435 & 63.4 & 9718 & 0.0989 & 0.1420 & 1.800 & 0.09198 & 856 & 1046 & 1467 \\
\hline $9: \mathrm{Zr}<75$ na. ja. [19] & 0.024 & 730 & 72.7 & 1523 & 0.0970 & 0.09774 & 0.8585 & 0.06371 & 601 & 629 & 732 \\
\hline 10:Zr <75 na. ja. [25] & 0.026 & 1190 & 128 & 7132 & 0.0838 & 0.1081 & 1.037 & 0.06955 & 662 & 722 & 915 \\
\hline $11:$ Mz na. $>75$ & 0.092 & 5871 & 1615 & 2120 & 2.324 & 0.09301 & 0.7592 & 0.05920 & 573 & 574 & 574 \\
\hline $12:$ Mz na. $>75$ & 0.048 & 6131 & 1785 & 1366 & 2.500 & 0.09305 & 0.7595 & 0.05920 & 574 & 574 & 574 \\
\hline $13:$ Mz na. $<75$ & 0.047 & 5559 & 1763 & 2592 & 2.858 & 0.09277 & 0.7564 & 0.05914 & 572 & 572 & 572 \\
\hline
\end{tabular}

Table 2 - Rb-Sr and Sm-Nd analytical results for the Urucum suite granitoids.

\begin{tabular}{|c|c|c|c|c|c|c|c|c|c|c|c|c|c|}
\hline Sample & Facies & $\begin{array}{c}\mathrm{Sm} \\
(\mathrm{ppm})\end{array}$ & $\begin{array}{c}\mathrm{Nd} \\
(\mathrm{ppm})\end{array}$ & $\frac{{ }^{147} \mathrm{Sm}}{{ }^{144} \mathrm{Nd}}$ & $\begin{array}{l}\underline{{ }^{143} \mathrm{Nd}} \\
{ }^{144} \mathrm{Nd} \pm 2 \sigma_{(\mathrm{M})}\end{array}$ & $\varepsilon \mathrm{Nd}_{(\mathrm{T})}$ & $\begin{array}{c}\mathrm{T}_{\text {CHUR }} \\
\mathrm{Ma}\end{array}$ & $\begin{array}{l}\text { TD.M. } \\
\text { Ma }\end{array}$ & $\begin{array}{c}\mathrm{Rb} \\
(\mathrm{ppm})\end{array}$ & $\begin{array}{c}\mathrm{Sr} \\
(\mathrm{ppm})\end{array}$ & $\begin{array}{l}{ }^{87} \mathrm{Rb} \\
{ }^{86} \mathrm{Sr}\end{array}$ & $\begin{array}{l}{ }^{87} \mathrm{Sr} \\
{ }^{86} \mathrm{Sr} \pm 2 \sigma_{(\mathrm{M})}\end{array}$ & $\begin{array}{l}\frac{{ }^{87} \mathrm{Sr}}{(\mathrm{i})} \\
{ }^{86} \mathrm{Sr}\end{array}$ \\
\hline MD41A & Megafeldspar & 6.21 & 30.3 & 0.1238 & $0.511958 \pm 6$ & -7.9 & 1425 & 1840 & 214 & 75 & 8.32 & $0.78189 \pm 2$ & 0.7130 \\
\hline MD37 & Megafeldspar & 5.53 & 26.2 & 0.1276 & $0.511996 \pm 7$ & -7.5 & 1420 & 1860 & 248 & 55 & 13.2 & $0.82057 \pm 2$ & 0.7114 \\
\hline MD07-2 & Med. - to coarse & 4.61 & 19.5 & 0.1426 & $0.512038 \pm 7$ & -7.8 & 1695 & 2165 & 159 & 104 & 4.44 & $0.74965 \pm 2$ & 0.7129 \\
\hline CP05 & Tourmaline & 2.18 & 9.49 & 0.1388 & $0.512003 \pm 9$ & -8.2 & 1680 & 2125 & 165 & 59 & 8.15 & $0.78328 \pm 2$ & 0.7159 \\
\hline MD05C & Pegmatitic & 0.51 & 1.58 & 0.1947 & $\begin{array}{l}0.512256 \\
13\end{array}$ & -7.4 & - & - & 132 & 45 & 8.55 & $0.78721 \pm 2$ & 0.7165 \\
\hline
\end{tabular}

$\mathrm{T}=580 \mathrm{Ma} ; \mathrm{T}_{\mathrm{CHUR}}$ is calculated with Jacobsen and Wasserburg (1980) parameters; $\mathrm{T}_{\mathrm{D} . \mathrm{M} \text {. is calculated after De Paolo (1981) model; Mean of the La Jolla }}$ standards ${ }^{143} \mathrm{Nd} /{ }^{144} \mathrm{Nd}=0.511850 \pm 6(2 \sigma)$ 

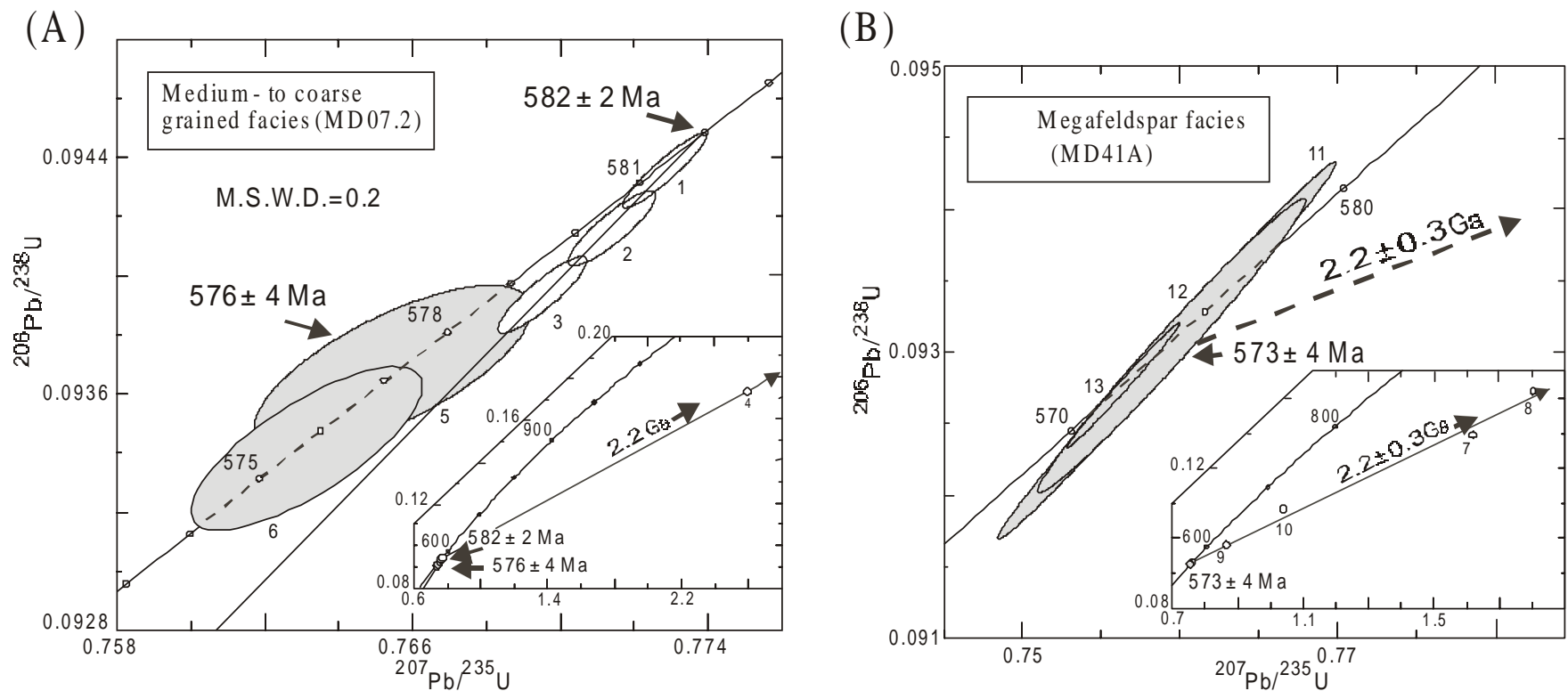

Figure 4 - U-Pb concordia diagram of the zircons and monazites (gray ellipses) of the Urucum Suite (medium- to coarse grained facies - diagram A and megafeldspar facies - diagram B).

\section{References}

Almeida F.F.M. 1977. O Craton do São Francisco. Rev. Bras. Geoc., 7:349-364. Almeida F.F.M., Hasui Y. 1984. O Precambriano do Brasil. Edgard Blücher, São Paulo,

378p.
Almeida F.F.M., Hasui Y, Brito Neves B.B., Fuck, R.A. 1981. Brazilian structural provinces: an introduction. Earth Science Reviews, 17:1-29.

Barbosa A.L.M., Sad J.H.G., Torres N., Melo M.T.V. 1964. Geologia das quadrículas Barra do Cuité e Conselheiro Pena, MG. Relatório do Arquivo Técnico do DGM, 64 DNPM, Rio de Janeiro. 285p

Batchelor R.A., Bowden P. 1985. Petrogenetic interpretation of granitoids series using multicationic parameters. Chem. Geol., 48:43-55.

Bateman P.C. \& Chappell B.W. 1979. Crystallization fractionation and solidification of the Tuolumne Intrusive Series, Yosemite National Park, California. Bull. Geol. Soc. Amer., 90:465-482.

Burnham C.W. 1967. Hydrothermal fluids at the magmatic stage. In Geochemistry of Hydro thermal Ore Deposits (ed. H.L Barnes). Holt, Rinehart and Winston, Inc. $670 \mathrm{p}$.

Campos Neto M.C. \& Figueiredo M.C.H. 1995. The Rio Doce orogeny, southeastern Brazil. J.of South American Earth Sciences, 8(2):143-162.

Chappell B.W. \& White A.J.R. 1974. Two contrasting granite types. Pacific. Geol., 8:173174 .

Chappell B.W. \& White A.J.R. 1992. I- and S-type granites in the Lachlan fold belt. Trans. of the Royal Soc. of Edinburgh, Earth Sci., 83:1-26.

Chevremont P., Gagny C., La Roche H. de, Pupin J. P., Rossi P. 1988. Représentation cartographique du plutonisme acide et du plutonisme intemédiaire à basique associé. Documents du BRGM, $\mathrm{n}^{\circ} 152,61 \mathrm{p}$

Cordani U. G., Teixeira W., Tassinari C. C. G., Kawashita K., Sato K. 1988. The growth of Brazilian Shield. Episodes, 11:163-166.

Cunningham W. D., Marshak S., Alkmim F. F. 1996. Structural style of basin inversion at mid-crustal levels: two transects in the internal zone of the Brasiliano Araçuaí Belt, Minas Gerais, Brazil. Precambrian Research, 77:1-15.

De Paolo D. J. 1981. Trace element and isotopic effects of combined wall rock assimilation and fractional crystallization. Earth Planet. Sci. Lett., 53:189-202.

Ebert H. D., Chemale Jr. F., Babinsky M., Artur A. C., Van Schumus W. R. 1996. Tectonic setting and U-Pb zircon dating of Socorro Complex in the transpressive Rio Paraíba do Sul Shear belt, SE Brazil. Tectonics, 15:688-699.

Fanton J.J., Arioli E.A., Moura O.J.M. 1978. Pegmatitos da região de Galiléia - Mendes Pimentel, MG. In: XXX Congresso Brasileiro de Geologia, Anais, Recife, 4:17701781.

Figueiredo M.C.H. \& Campos Neto M.C. 1993. Geochemistry of the Rio Doce magmatic arc, Southeastern Brazil. An. da Acad. bras Ciên., 65:63-81.

Gray C. M. 1984. An isotopic mixing model for the origin of granitic rocks in southeastern Australia. Earth Planet. Sci. Lett., 70:47-60.

Green T.H. 1977. Garnet in silicic liquids and its possible use as a P-T indicator. Contrib. Mineral. Petrol., 65:59-67.

Guidotti C.V., Cheney J.T., Guggenheim S. 1977. Distribution of titanium between coexisting muscovite and biotite in pelitic schists from northwestern Maine. Am. Mineral., 62:438-448.

Jacobsen S.B. \& Wasserburg G.J. 1980. Sm-Nd isotopic evolution of chondrites. Earth Planet. Sci. Lett., 50:139-155.

Kerrick D. M. 1972. Experimental determination of muscovite + quartz stability with $\mathrm{pH}_{2} \mathrm{O}<\mathrm{p}_{\mathrm{T}}$. Amer. J. Sci. 272:946-958.

La Roche H. de, Leterrier J., Granclaude P., Marchal M. 1980. A classification of volcanic and plutonic rocks using R1-R2 diagram and major-element analyses - its relationships with current nomenclature. Chemical Geology, 29:183-210.

Leonardos O. H. \& Fyfe W.S. 1974. Ultrametamorphism and melting of a continental margin: the Rio de Janeiro region, Brazil. Contrib. Mineral. Petrol., 46:201-214.

Machado R. 1997. Litogeoquímica e tectônica dos granitóides Neoproterozóicos do cinturão Paraíba do Sul no Estado do Rio de Janeiro. Tese de livre docência. Instituto de Geociências/Universidade de São Paulo, 215p.

Maniar P.D. \& Piccoli P.M. 1989. Tectonic discrimination of granitoids. Geological Soc. Am. Bull., 101:635-643.
Mascarenhas J. F. 1979. Evolução geotectônica do Precambriano do oeste da Bahia. In: H.V.A. Inda (editor), Geologia e Recursos Minerais do Estado da Bahia, SME-BA, Textos Básicos, 2:25-53.

Miller C.F. \& Stoddard E.F. 1980. The role of manganese in the paragenesis of magmatic garnet: an example from the Old Woman-Piute range, California. J. of Geology.,

Miller C. F., Stoddard E.F., Larry J.B., Wayne A.D. 1981. Composition of plutonic muscovites: genetic implications. Can. Miner., 19:25-34

Monier G., Mergoil-Daniel J., Labernardière H. 1984. Générations successives de muscovites et feldspaths potassiques dans les leucogranites du massif de Millevaches (Massif Central français). Bull. Minéral., 107:55-68.

Monier G. \& Robert J. L.. 1986. Muscovite solid solutions in system $\mathrm{K}_{2} \mathrm{O}-\mathrm{MgO}-\mathrm{FeO}$ $\mathrm{Al}_{2} \mathrm{O}_{2}-\mathrm{SiO}_{2}-\mathrm{H}_{2} \mathrm{O}$ : an experimental study at $2 \mathrm{kbar} \mathrm{PH}_{2} \mathrm{O}$ and comparison with natu$\mathrm{ral}^{2} \mathrm{Li}$-free white micas. Miner. Mag., 50:257-266.

Montel J. M. 1993. A model for monazite/melt equilibrium and application to the generation of granitic magmas. Chem. Geol., 110:127-146.

Moura O.J.M., Fanton J.J., Arioli E.A. 1978 Geologia da região de Galiléia - Mendes Pimentel, Minas Gerais. In: XXX Congresso Brasileiro de Geologia, Anais, Recife, 1:26-37.

Nachit H., Razafimahefa N., Stussi J.M., Carron J.P. 1985. Composition chimique des biotites et typologie magmatique des granitoïdes. C.R. Acad. Paris, t. 301, série II, $\mathrm{n}^{\circ} 11,813-818$

Nalini Jr. H. A. 1997. Caractérisation des suites magmatiques néoproterozö̈ques de la région de Conselheiro Pena et Galiléia (Minas Gerais, Brésil). Etude géochimique et structurale des suites Galiléia et Urucum et relation avec les pegmatites à éléments rares associées. Thèse de doctorat. Ecole Nationale Supérieure de Mines de Paris et de Saint Etienne. 237p.

Porada H. 1989. Pan-African rifting and orogenesis in southern to equatorial Africa and Easterrn Brazil. Precambrian Research, 44:103-136.

Pupin J.P. 1976. Signification des caractères morphologiques du zircon commun des roches en pétrologie. Base de la méthode typologique. Applications. Thèse, Univ. Nice, 392p.

Silva J M. L Lima M I.C Veronese V.F, Ribeiro Jr R. N., Rocha R.M. Siga Jr O 1987. Geologia. In: Projeto Radambrasil, Folha SE.24 - Rio Doce, Levantamento de Recursos Naturais, $34,544 \mathrm{p}$

Stacey J.S. \& Kramers J.D. 1975. Approximation of terrestrial lead isotope evolution by a two-stage model. Earth Planet. Sci. Lett., 26:207-221.

Steiger R. H. \& Jäeger E. 1977. Subcommission on geochronology: convention on the use od decay constants in geo and cosmochronology. Earth Planet. Sci. Lett, 36:359-362.

Thiéblemont D. \& Cabanis B. 1990. Utilisation d'un diagramme (Rb/100)-Tb-Ta pour la discrimination géochimique et l'étude pétrogénetique des roches magmatiques acides. Bull. Soc. géol. France, t. VI, 8(1):23-35.

Valladares C. 1996. Evolução geológica do complexo Paraíba do Sul, no segmento central da Faixa Ribeira, com base em estudos de geoquímica e geocronologia $U-P b$. Tese de Doutorado, Instituto de Geociências/Universidade de São Paulo, $147 \mathrm{p}$.

Vidal P., Cocherie A., Le Fort P. 1982. Geochemical investigation of the origin of the Manaslu leucogranite (Himalaya, Nepal). Geochim. Cosmochim. Acta, 46:22792292.

Vidal P., Bernard-Griffiths J., Cocherie A., Le Fort P., Peucat J., Sheppards S. M. F. 1984 Geochemical comparison between Himalayan and Hercynian leucogranites. Phys. Earth Planet. Int., 35:179-190.

Watson E.B. \& Harrison T.M. 1984. Accessory minerals and the geochemical evolution of crustal magmatic systems: a summary and prospectus of experimental approaches. Phys. Earth Planet. Int., 35:19-30.

White A. J. R. \& Chappell B. W. 1977. Ultrametamorphism and granitoid genesis. Tectonophysics, 43:7-22.

Manuscript IGC-138

Received March 1, 2000 Accepted for publication April 30, 2000 